\title{
Is biofuel policy harming biodiversity in Europe?
}

\author{
JEANNETTE EGGERS*, KATJATRÖLTZSCH*, ALESSANDRAFALCUCCI†, LUIGI

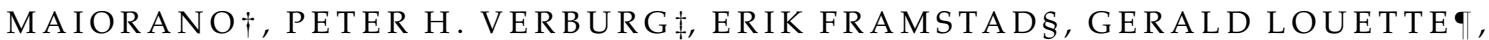 \\ DIRK MAES $\uparrow$, SZABOLCS NAGY**, WIM OZINGA $\dagger \dagger$ and BEN DELBAERE $+\ddagger$ \\ ${ }^{*}$ European Forest Institute, Torikatu 34, 80100 Joensuu, Finland, $\uparrow$ Department of Animal and Human Biology, Sapienza University \\ of Rome, Viale, dell'Università 32, I-00185 Rome, Italy, łLand Dynamics Group, Wageningen University, PO Box 47, 6700 AA \\ Wageningen, The Netherlands, §Norwegian Institute for Nature Research, Gaustadalleen 21, N-0349 Oslo, Norway, Research \\ Institute for Nature and Forest, Kliniekstraat 25, B-1070 Brussels, Belgium, ||Butterfly Conservation Europe, PO Box 506, NL-6700 \\ AM Wageningen, The Netherlands, **Wetlands International, PO Box 471, NL-6700 AL Wageningen, The Netherlands, \\ $\dagger \dagger$ Wageningen UR, Alterra, Centre for Ecosystem Studies, PO Box 47, NL-6700 AA, Wageningen, The Netherlands, \\ $\ddagger \ddagger E C N C$ - European Centre for Nature Conservation, PO Box 90154, 5000 LG Tilburg, The Netherlands
}

\begin{abstract}
We assessed the potential impacts of land-use changes resulting from a change in the current biofuel policy on biodiversity in Europe. We evaluated the possible impact of both arable and woody biofuel crops on changes in distribution of 313 species pertaining to different taxonomic groups. Using species-specific information on habitat suitability as well as land use simulations for three different biofuel policy options, we downscaled available species distribution data from the original resolution of 50 to $1 \mathrm{~km}$. The downscaled maps were then applied to analyse potential changes in habitat size and species composition at different spatial levels. Our results indicate that more species might suffer from habitat losses rather than benefit from a doubled biofuel target, while abolishing the biofuel target would mainly have positive effects. However, the possible impacts vary spatially and depend on the biofuel crop choice, with woody crops being less detrimental than arable crops. Our results give an indication for policy and decision makers of what might happen to biodiversity under a changed biofuel policy in the European Union. The presented approach is considered to be innovative as to date no comparable policy impact assessment has been applied to such a large set of key species at the European scale.

Keywords: biodiversity, biofuel crop type, biofuel policy, downscaling, Europe, habitat suitability, impact assessment, land-use change
\end{abstract}

Received 3 December 2008 and accepted 12 December 2008

\section{Introduction}

It is widely accepted that anthropogenic emissions of carbon dioxide $\left(\mathrm{CO}_{2}\right)$, together with other greenhouse gases, are leading to global climate change (Solomon et al., 2007). The necessity of reducing emissions of $\mathrm{CO}_{2}$ and other greenhouse gases has evolved into the establishment of climate-change strategies in the industrialized countries to comply with their quantitative commitments under the Kyoto Protocol (Simeonova, 2005). In this context, renewable energies are seen as

Correspondence: Jeannette Eggers, tel. + 35810773 4318, fax + 35810773 4377, e-mail: jeanette.eggers@efi.int one of the key options to mitigate $\mathrm{CO}_{2}$ emissions (EEA, 2006; Faaij, 2006; Fargione et al., 2008).

Transport is responsible for circa $25 \%$ of the energyrelated greenhouse gas emissions worldwide, and the increasing trend of emissions in this sector is foreseen to continue (Kahn Ribeiro et al., 2007). Compatible with many conventional engines and blendable with current fossil fuels, biofuels have potential to contribute to emission reductions in the transport sector (Farrell et al., 2006; Koh \& Ghazoul, 2008; Tan et al., 2008). Following Quadrelli \& Peterson (2007), oilseed-derived biodiesel leads to greenhouse gas reductions, on a well-to-wheel basis, of 40-60\% when compared with conventional petroleum diesel. However, biofuels are under heavy discussion in terms of economic 
cost-benefits and their environmental and social impacts. Currently, very high production costs form a barrier to a higher share of biofuels in the transport fuel mix, and energy input/output ratios are often marginal (Sims et al., 2006; Quadrelli \& Peterson, 2007). Moreover, the production of biofuels is criticized for competing with global food production, intensifying agricultural land use, increasing demands for irrigation, harming biodiversity and soil conditions, and for the potential contribution to green house gas emissions arising from land conversion, fertilizers and machinery (Koh, 2007; Biemans et al., 2008; Eickhout et al., 2008; Marshall, 2008; Rowe et al., 2008; Russi, 2008). Nevertheless, considering the increasing oil prices and the expected technological development in their production process, biofuels can potentially play an important role for the transport sector in the long-term planning (Åhman \& Nilsson, 2008; Mathiesen et al., 2008).

The production of biofuels and problems related to it received increasing attention in the European Union (EU) policy and will probably continue to do so. The EU promotes the production of biofuels through the application of the 'biofuels directive' (2003/30/EC Directive on the promotion of the use of biofuels and other renewable fuels for transport) which sets a target of $5.75 \%$ share of biofuels in the transport sector by 2010 for all the EU member states. In 2008 the European Commission presented a proposal for a new directive aiming at establishing an overall binding target for biofuels in transport (10\% minimum target) to be achieved by each member state by 2020 (Commission of the European Communities, 2008).

The cultivation of biofuel crops has a significant impact on land-use. Out of the total area of arable land in the 25 European Union (EU25) countries in 2005 (97 million ha), about 1.8 million ha were used for producing raw materials for biofuels (Commission of the European Communities, 2005). An increasing demand for biofuels could lead to the expansion of cultivated areas. Possible consequences are increasing environmental pressures, further habitat loss and biodiversity decline, especially if forest, grassland, peatland and wetlands are converted into monoculture plantations for the production of biofuels. However, in situations where energy crop plantations replace other monocultures the direct impacts on biodiversity are not likely to be significant (CBD, 2008).

Currently, biofuel crops are mainly grown as normal arable crops rich in sugar, starch or vegetable oil, such as cereals, maize or rape seed (EEA, 2007; Koh \& Ghazoul, 2008). An alternative to these first-generation biofuel crops are second-generation biofuel crops, produced from nonfood, ligno-cellulosic materials such as wood, energy grass or any other cellulosic biomass.
They are still under development, but are expected to play a vital role in the biofuel sector in the future when second generation production technologies will become operational (Tan et al., 2008). Ligno-cellulosic crops are already cultivated on a small scale, but currently used only for generating heat and electricity (Wright, 2006; EEA, 2007; Harvey, 2007; Rowe et al., 2008). Such perennial crop types are considered to have higher rates of energy savings and greenhouse gas reductions as well as better carbon sequestration possibilities compared with annual energy crops (Karp \& Shield, 2008; Schmer et al., 2008). From a biodiversity perspective the production of second-generation biofuel crops has several environmental advantages over the cultivation of arable crops: longer rotation periods, lower fertilizer and pesticide input, and better soil protection (EEA, 2007). Although the effects of perennial crops on landscape structure can be substantial due to their growing size of 2 to $5 \mathrm{~m}$, they may have a positive function on landscape diversity and can create valuable habitat and shelter for certain mammals and bird species when grown as strips and not over large areas (EEA, 2007). Potential implications for hydrology and biodiversity result from their generally high water use due to deep rooting (Karp \& Shield, 2008) and the risk of introduced crops becoming invasive (Raghu et al., 2006).

Through its impact on land use, the production of biomass for biofuel also has a significant effect on the EU's target of halting the loss of biodiversity by 2010 . There is an increasing need for cost-effective tools to assess the impact of EU policy measures on biodiversity (Delbaere, 2006). This paper presents an innovative method to assess biodiversity impacts resulting from changing land use due to the production of biofuel crops in Europe, distinguishing between arable (firstgeneration) and woody (second-generation) crop types. In particular we focus on two questions: (1) what might happen if we doubled the current EU biofuel target, and (2) what might happen if we abolished the current biofuel target. While biodiversity as such includes all forms of life, our impact assessment is restricted to a set of 313 species pertaining to four taxonomical groups.

\section{Materials and methods}

\section{Input data}

Species-specific information. Species-specific information was obtained from a database created within the BioScore project funded through the EC Sixth Framework Programme for Research and Technical Development. As it is practically impossible to work with the whole set of animal and plant species occurring in Europe, many of which are currently still 
unknown (Mace, 2004), the number of species considered in the BioScore database is reduced to a subset of species, following selection criteria described in (Louette et al., unpublished data). The database provides information on environmental requirements (e.g. land cover and elevation ranges), and sensitivity to various pressures (e.g. fragmentation, pollution, climate change) for 2163 species, belonging to eight taxonomical groups (mammals, reptiles, amphibians, birds, vascular plants, freshwater fish, aquatic macrobenthos, and butterflies). In this study, we considered mammals, reptiles, amphibians, and birds, and in particular those species for which detailed and reliable European distribution data at a resolution of $50 \mathrm{~km}$ were available (313 species, see Table 1). These species-specific distribution maps (presence/absence) are based on a number of data sources (Hagemeijer \& Blair, 1997; Mitchell-Jones et al., 1999; Gasc et al., 2004; Linnell et al., 2007; Temple \& Terry, 2007) which characteristics have been summarized in Delbaere \& Nieto Serradilla (2004). A list of the species considered in this study is available in the online supporting information Table S1.

To address the potential impacts of land use changes resulting from biofuel crop production, we applied information on the suitability of different land cover classes as potential habitat for each species, and the elevation ranges (minimum and maximum elevation) in which each species occurs, from the BioScore database. Elevation ranges were not available for birds. The database distinguishes four different levels of habitat suitability ('suitability levels') which vary depending on land cover and biogeographical region (BGR): unsuitable, low, medium and high suitability (Maiorano et al., 2007). The land cover classes considered follow the CORINE land cover classification (level 3, EEA, 2000). For each species, the IUCN Red List (IUCN, 2008) provided information on

Table 1 Number of species in Europe, number of species retained in the BioScore database, and number of species considered in this study, for the analysed species groups

\begin{tabular}{llll}
\hline & $\begin{array}{l}\text { Total number } \\
\text { of species } \\
\text { occurring }\end{array}$ & $\begin{array}{l}\text { Retained } \\
\text { number in } \\
\text { BioScore } \\
\text { database }\end{array}$ & $\begin{array}{l}\text { Number of } \\
\text { species } \\
\text { considered } \\
\text { in this } \\
\text { study }\end{array}$ \\
\hline Birds & 526 & 518 & 204 \\
Mammals & 295 & 61 & 60 \\
Reptiles & 217 & 29 & 29 \\
Amphibians & 88 & 20 & 20 \\
Total & 1126 & 628 & 313 \\
\hline
\end{tabular}

the conservation status. Data on elevation covering the entire study area was obtained from the GTOPO30 digital elevation model for Europe at $1 \mathrm{~km}$ resolution (USGS, 2006). The study area was divided into 11 BGR as defined by the European Environment Agency (EEA, 2005b) at a scale of $\geq 1: 10000000$.

Land use scenario. The effects of the implementation of the biofuels directive on land use were evaluated by the EUruralis 2.0 project (Rienks, 2008; Verburg et al., 2008; WUR, MNP, 2008) based on a land use scenario for the $27 \mathrm{EU}$ countries for the period 2000 to 2030 at $1 \mathrm{~km}$ resolution. This 'Global Economy' scenario assumes a continuing globalization with open borders, limited trade barriers, rapid economic growth, strong economic development and low levels of government intervention resembling the scenario conditions of the Special Report on Emissions Scenarios of the International Panel on Climate Change (SRES IPCC) A1 scenario (Nakicenovic \& Swart, 2000; Westhoek et al., 2006). Within this scenario three policy options are explored related to the biofuels directive:

- Policy option (e1) of no or low ambition on biofuels: $0 \%$ blending obligation on share of biofuels in transport sector in 2010 and kept constant afterwards.

- Policy option (e2) of medium ambition on biofuels: $5.75 \%$ blending obligation on share of biofuels in transport sector in 2010 and kept constant afterwards.

- Policy option (e3) of high ambition on biofuels: $11.5 \%$ blending obligation on share of biofuels in transport sector in 2010 and kept constant afterwards.

In all three-policy options (e1, e2, e3), the biofuel ambitions are assumed to be solely met by first generation biofuel crops. Furthermore, in its current implementation, increased biofuel ambitions in other world regions are disregarded (Banse et al., 2008). The amount of biofuels produced within the EU27 to meet the biofuel targets depends on global trade policies that determine the share of biofuels domestically produced and imported in combination with changing food and feed supply and demand. The land use projections are output of a combination of different models, including a global general equilibrium model (van Meijl et al., 2006; Banse et al., 2008), an integrated assessment model that accounts for environmental and land-based impacts (Eickhout et al., 2007), and the Dyna-CLUE model applied to spatially allocate the different land uses (Verburg et al., 2006; Hellmann \& Verburg, 2008). Be- 
sides biofuel crops the land use simulation includes 17 categories of land use which are based on an aggregation of the CORINE legend (EEA, 2000). Within the arable land category the most likely locations for biofuel crop production are simulated by accounting for transport costs to likely locations of processing industry, land suitability and rotation systems (Hellmann \& Verburg, 2008). Scenario conditions include the scale of the processing industry, transportation constraints, the use of set-aside land and restricted areas (such as the NATURA2000 designated areas). Although limited to the EU27 area, the policy options imply impacts on other world regions too, due to the assumption of a global trade in the food, feed and bioenergy sector. However, with our study we focus only on the biodiversity impacts within the EU. For global impacts we refer to the analysis in WUR, MNP (2008) and Banse et al. (2008).

The policy option of medium ambition (e2) can be considered as a reference scenario, as it reflects the currently implemented target of the EU biofuels directive. The e1 policy option indicates the abolishment of the biofuel target, while the e3 policy option reflects a doubling of the current target. The area devoted to the cultivation of biofuel crops increases from $0.5 \%$ of total land area in the year 2000 to $1.2 \%, 2.7 \%$ and $3.9 \%$ of total land area in the year 2030 for the policy options e1, e2 and e3, respectively. The land use projections in all three policy options are attributed to different factors, such as demographic and economic development as well as agricultural and several other policies including biofuel targets (Westhoek et al., 2006). However, the biofuel policy options differ from each other only in the biofuel target, whereas all other policies are kept constant. Thus any difference among e1, e2 and e3 is linked to biofuel policy. Therefore, comparing the policy options allows us to quantify the relative impact of biofuel policy on land use, and thus to link the subsequent land use changes to impacts on biodiversity. Besides the land use projections for the three policy options, also a base map for the year 2000 following the same land use classification scheme was used in this study.

\section{Method}

Our approach is based on two main steps. In a first step, we applied a downscaling of the original species distribution data from 50 to $1 \mathrm{~km}$ resolution, by linking the land use projections (e1, e2, e3) and the year 2000 land use map with the species-specific information on distribution and habitat suitability. The downscaling was performed in connection with two different biofuel crop types (first- and second-generation crops). In a second step, the downscaled distribution data for the different biofuel policy and crop options were compared with each other to assess biodiversity impacts of changes in the biofuel crop production.

Downscaling of the species distribution maps. The speciesand region-specific habitat suitability levels and elevation ranges were used to downscale and refine the available species distribution data (presence/ absence) from the original resolution of $50 \mathrm{~km}$ to a resolution of $1 \mathrm{~km}$ for the biofuel policy options (year 2030) and the base year 2000. This means that for every species and each possible combination of land use type, elevation and BGR, the related habitat suitability level was queried from the BioScore database. The habitat suitability levels were then linked with the maps on land use type (year 2000, e1, e2, e3), elevation and BGR in order to identify areas where a species potentially occurs within its distribution area. The resulting downscaled distribution maps present habitat suitability levels within the area of species presence.

The land use classes for the policy options are simulated based on a generalization of the CORINE land cover classes used in the BioScore database. A conversion had to be applied to link these two classification schemes and derive information on habitat suitability for the biofuel policy options. To establish such a conversion, the base map for the year 2000 was combined with the CORINE 2000 map. The dominant CORINE class(es) were identified for each class of the base map in each BGR. If several CORINE classes were codominant in one land use class of the base map, multiple CORINE classes were linked to that land use class. In such case the maximum suitability level for these CORINE classes from the BioScore database was assigned to the respective land use class in the land use maps of the biofuel policy options. This was the case for (semi-)natural vegetation (in five regions), forest (in four regions), pastures (in three regions), permanent crops (in two regions), and sparsely vegetated areas (in one region). For example, in the alpine region, the three CORINE classes 'broadleaved forest', 'coniferous forest' and 'mixed forest' are codominant within the area covered by the class 'forest' of the year 2000 base map. In the alpine region, coniferous forest provides highly suitable habitat for red squirrels (Sciurus vulgaris L.) and the species has only a medium suitability in broadleaved and mixed forests. Choosing the maximum suitability level as explained above, we therefore assigned high habitat suitability to the class 'forest' in the downscaled maps for red squirrel in the alpine region.

In the European biofuel policy options, only first generation biofuel crops are considered. In order to analyse the impact of cultivating different crop types 
on biodiversity, we assumed in a comparative analysis that woody crops would be cultivated instead of arable biofuel crops at the same sites. Thus, we needed to consider two crop options when downscaling the distribution maps: (a) first generation biofuel crops (arable crops such as maize, wheat or potatoes), cultivated at all sites marked as 'biofuel crops' in the policy options; and (b) second generation woody biofuel crops (short-rotation woody crops such as willow and poplar), cultivated at all sites marked as 'biofuel crops' in the policy options. In order to differentiate between the species-specific habitat suitabilities of different crop types, the land use class 'biofuel crops' was linked with the habitat suitability level of the CORINE class 'arable land' to analyse impacts of first-generation arable biofuel crops (hereafter referred to as option 'arable'), and with habitat suitability of the CORINE class 'fruit trees and berry plantations' used as a proxy for woody crop plantations to study impacts of second-generation woody biofuel crops (hereafter referred to as option 'woody'). For birds, in addition to the suitability levels per CORINE land cover class as given in the BioScore database, explicit habitat suitability levels for woody crops were available. Therefore we linked these levels to the woody crop option in our analysis for birds.

Comparison of the biofuel policy and crop options. The comparison of the biofuel policy options considers the impacts of (1) doubling the current biofuel target (e3 vs. e2), and (2) abolishing the current biofuel target (e1 vs. e2). Both comparisons were assessed for the arable crop option. In order to compare the impacts of arable and woody crops, we also analysed the differences between the woody and the arable crop option for the e2 scenario. Additionally, we studied the land use changes between the base year 2000 and the e 2 policy option for 2030 to put our results into perspective of the overall land use changes ('overall development') projected for this period in the EUruralis Global Economy scenario.

Following the approach adopted by Maiorano et al. (2007), the habitat suitability levels of the downscaled distribution maps were grouped into two classes: potential species presence (medium and high suitable habitat) and potential species absence (unsuitable and low suitable habitat or species not present). The resulting binary maps were used to calculate for each species group, and for all species combined, the total number of species potentially occurring in each $1 \mathrm{~km} \times 1 \mathrm{~km}$ grid cell. Based on these totals, differences between the biofuel policy options were calculated at European level.

\section{Changes in the size of suitable habitat}

At the level of BGR we analysed which species might gain or lose habitat if the biofuel target was doubled or abolished, and if woody crops would be cultivated instead of arable crops, relative to the reference policy option e2. In addition we evaluated the habitat size changes occurring between the base year 2000 and 2030 for the e2 policy option. To concentrate on major changes in potential habitat size, we considered only those changes exceeding an increase or decrease of $1 \%$ of the potential habitat of the species in a BGR. In all other cases the potential habitat was considered as stable. The resulting figures were used to derive the percentage of species occurring in a BGR which might increase, decrease or keep their potential habitat size under the different assumptions. These analyses were also carried out with attention to the conservation status of the species. To derive the number of threatened species impacted, the IUCN Red List categories 'near threatened', 'vulnerable', 'endangered' and 'critically endangered' were aggregated. Applying this aggregation, 74 Red-listed species which are threatened in (parts of) the EU were covered in this study.

\section{Changes in species composition and total species number}

Moreover, we analysed the potential change in species composition between the different biofuel policy options, the two biofuel crop types, and between the base year 2000 and year 2030. It was calculated as the ratio between the number of species potentially gaining or losing their entire habitat in each $1 \mathrm{~km} \times 1 \mathrm{~km}$ cell when comparing the policy options, and the total species number (based on the e2 option) of that cell. When studying the potential change in species composition for the period 2000-2030, the total species numbers in the base year 2000 were used as reference values, while we applied the species numbers of the e 2 arable option for the comparison between arable and woody crop choice. We consider it a species loss when one or more species potentially lose their entire habitat in a $1 \mathrm{~km} \times$ $1 \mathrm{~km}$ grid cell, while species gain occurs when one or more species potentially gain habitat in a $1 \mathrm{~km} \times 1 \mathrm{~km}$ grid cell where they were not present before.

For visualization purposes we aggregated the outcomes of this analysis at the level of $50 \mathrm{~km} \times 50 \mathrm{~km}$ cells. In particular, to each $50 \mathrm{~km} \times 50 \mathrm{~km}$ cell we assigned the percentage of area potentially gained or lost within this cell by $>50 \%$ of the species, having the policy option e 2 as reference. For the comparison between 2000 and 2030 the base year 2000 served as reference. From this analysis, we excluded cells with less than six species (corresponding to $<1 \%$ of the study area), as they were 
considered as unrepresentative. The relative changes in species composition were calculated for all taxonomical groups combined.

In addition, we analysed the area with a potential change in total species number for each species group, based on the difference in the total number of species potentially occurring for each $1 \mathrm{~km} \times 1 \mathrm{~km}$ grid cell between the policy options, between the two crop types, and for the period 2000-2030.

All analyses were based on the EU27 area following the spatial coverage of the land use simulations.

\section{Results}

Changes in the size of suitable habitat between the biofuel policy and crop options

The potential impact of biofuel plantations on species occurrence varies among BGR and species groups (Table 2). For example, $28 \%$ of the mammal species occurring in the boreal region might lose potential habitat if the biofuel target was abolished, while the effect on mammals is largely positive in the other BGRs.

Table 2 Percentage of species possibly losing or gaining $>1 \%$ of their potential habitat if the biofuel target is abolished (e1-e2) or doubled (e3-e2), if the crop type is changed (woody-arable), and between 2000 and 2030 overall (e2-2000), per biogeographical region (BGR)

\begin{tabular}{|c|c|c|c|c|c|c|c|c|c|c|c|c|c|}
\hline \multirow[b]{2}{*}{ BGR } & \multirow[b]{2}{*}{ \# } & \multicolumn{3}{|c|}{$\begin{array}{l}\text { Overall change between } \\
2000 \text { and } 2030 \\
\text { Comparison e2-2000 } \\
\text { (in \%) }\end{array}$} & \multicolumn{3}{|c|}{$\begin{array}{l}\text { What might change in } \\
\text { addition if we abolish the } \\
\text { current biofuel target? } \\
\text { Comparison e1-e2 (in \%) }\end{array}$} & \multicolumn{3}{|c|}{$\begin{array}{l}\text { What might change in } \\
\text { addition if we double the } \\
\text { current biofuel target? } \\
\text { Comparison e3-e2 (in \%) }\end{array}$} & \multicolumn{3}{|c|}{$\begin{array}{l}\text { What might change in } \\
\text { addition if we cultivate } \\
\text { woody instead of arable } \\
\text { crops? Comparison } \\
\text { woody-arable in e2 (in \%) }\end{array}$} \\
\hline & & Decrease & Stable & Increase & Decrease & Stable & Increase & Decrease & Stable & Increase & Decrease & Stable & Increase \\
\hline \multicolumn{14}{|l|}{ Amphibians } \\
\hline Alpine & 17 & 35 & 35 & 29 & 6 & 76 & 18 & 24 & 65 & 12 & 6 & 88 & 6 \\
\hline Atlantic & 16 & 25 & 19 & 56 & 0 & 50 & 50 & 75 & 25 & 0 & 6 & 88 & 6 \\
\hline Black sea & 8 & 25 & 63 & 13 & 0 & 88 & 13 & 0 & 100 & 0 & 0 & 100 & 0 \\
\hline Boreal & 10 & 50 & 30 & 20 & 40 & 60 & 0 & 30 & 70 & 0 & 0 & 100 & 0 \\
\hline Continental & 17 & 24 & 0 & 76 & 0 & 29 & 71 & 71 & 24 & 6 & 6 & 88 & 6 \\
\hline Mediterranean & 19 & 32 & 32 & 37 & 0 & 63 & 37 & 47 & 32 & 21 & 5 & 89 & 5 \\
\hline Pannonian & 12 & 83 & 0 & 17 & 0 & 17 & 83 & 50 & 42 & 8 & 0 & 92 & 8 \\
\hline \multicolumn{14}{|l|}{ Mammals } \\
\hline Alpine & 58 & 16 & 12 & 72 & 9 & 79 & 12 & 57 & 38 & 5 & 9 & 64 & 28 \\
\hline Atlantic & 48 & 21 & 8 & 71 & 0 & 60 & 40 & 71 & 19 & 10 & 6 & 63 & 31 \\
\hline Black sea & 41 & 29 & 49 & 22 & 0 & 66 & 34 & 0 & 100 & 0 & 0 & 100 & 0 \\
\hline Boreal & 36 & 44 & 36 & 19 & 28 & 69 & 3 & 69 & 22 & 8 & 6 & 61 & 33 \\
\hline Continental & 58 & 14 & 10 & 76 & 7 & 10 & 83 & 86 & 10 & 3 & 9 & 64 & 28 \\
\hline Mediterranean & 56 & 23 & 29 & 48 & 7 & 29 & 64 & 77 & 16 & 7 & 5 & 64 & 30 \\
\hline Pannonian & 51 & 73 & 10 & 18 & 4 & 45 & 51 & 49 & 51 & 0 & 10 & 59 & 31 \\
\hline \multicolumn{14}{|l|}{ Reptiles } \\
\hline Alpine & 23 & 52 & 35 & 13 & 0 & 78 & 22 & 9 & 83 & 9 & 0 & 87 & 13 \\
\hline Atlantic & 12 & 25 & 33 & 42 & 8 & 58 & 33 & 33 & 50 & 17 & 8 & 92 & 0 \\
\hline Black sea & 11 & 45 & 36 & 18 & 0 & 36 & 64 & 0 & 100 & 0 & 0 & 100 & 0 \\
\hline Boreal & 3 & 33 & 67 & 0 & 33 & 67 & 0 & 0 & 67 & 33 & 0 & 100 & 0 \\
\hline Continental & 22 & 23 & 14 & 64 & 0 & 32 & 68 & 50 & 50 & 0 & 5 & 77 & 18 \\
\hline Mediterranean & 29 & 38 & 45 & 17 & 3 & 38 & 59 & 62 & 38 & 0 & 3 & 76 & 21 \\
\hline Pannonian & 6 & 0 & 17 & 83 & 0 & 33 & 67 & 17 & 67 & 17 & 0 & 83 & 17 \\
\hline \multicolumn{14}{|l|}{ Birds } \\
\hline Alpine & 180 & 35 & 45 & 20 & 12 & 82 & 6 & 15 & 70 & 15 & 14 & 76 & 10 \\
\hline Atlantic & 163 & 33 & 41 & 26 & 1 & 69 & 30 & 37 & 53 & 9 & 14 & 75 & 11 \\
\hline Black sea & 133 & 32 & 40 & 29 & 5 & 62 & 34 & 1 & 85 & 14 & 0 & 100 & 0 \\
\hline Boreal & 142 & 21 & 49 & 30 & 16 & 75 & 9 & 24 & 63 & 13 & 14 & 73 & 13 \\
\hline Continental & 177 & 29 & 42 & 29 & 6 & 48 & 46 & 35 & 50 & 15 & 14 & 76 & 10 \\
\hline Mediterranean & 167 & 37 & 38 & 26 & 8 & 51 & 41 & 41 & 39 & 20 & 14 & 74 & 12 \\
\hline Pannonian & 136 & 38 & 32 & 30 & 7 & 57 & 37 & 36 & 62 & 2 & 17 & 70 & 13 \\
\hline
\end{tabular}

The second column (\#) gives the total number of species per BGR and species group considered in the analyses. 
Besides the regional differences, these numbers also indicate that for most of the regions and species groups, the amount of species that might lose habitat when doubling the current biofuel target far outweighs the amount of species that might gain habitat. The potentially negative impacts of a doubled target are largest for mammals, especially in the continental region. This is particularly of concern for species like Elk (Alces alces), East European hedgehog (Erinaceus roumanicus), Dormouse (Dryomys nitedula) and Etruscan shrew (Suncus etruscus), which also show a potentially decreasing trend for the overall development between 2000 and 2030. Thus, doubling the target might increase the already existing pressure on those species. More species would win rather than lose potential habitat if the current biofuel target was abolished. Only in the Boreal zone the situation is different, as here potential habitat loss is higher than habitat gain for all species groups if abolishing the current target. The impact of cultivating woody instead of arable biofuel crops is positive for mammals and reptiles - more species might win rather than lose potential habitat. For birds, the effect would be slightly negative, while the crop option choice has only a small impact on amphibians.

When comparing the changes in potential habitat size arising from different biofuel policies to the changes resulting from the overall development between 2000 and 2030 (Table 2), we can notice that the impacts of biofuel policies are strong. In many cases the number of species affected by habitat size changes related to a change in biofuel target exceeds the number of species concerned by the changes between 2000 and 2030 under the current target. This is especially valid for amphibians, reptiles and mammals where a doubling of the biofuel target would mean in many regions an additional potential habitat loss for much more species than those already affected by the overall changes happening within 30 years. Looking at the species group totals (Fig. 1), we can identify the Mediterranean, Continental and Atlantic zone as most affected by a doubling of the biofuel target (Fig. 1b) when comparing to the overall changes between 2000 and 2030 (Fig. 1d). An abolishment of the target (Fig. 1a) would have a potentially stronger positive effect for most of the species than the expected positive development between 2000 and 2030 in most of the regions. Changes in the choice of the biofuel crop type (Fig. 1c) have a smaller impact on habitat size changes compared with the overall development until 2030. The trends in potential habitat size changes are similar when only Red List species are considered (Fig. 2). However, some differences exist. For example, there is no negative impact of doubling the biofuel target on the considered Red List species in the Alpine region (Fig. 2b). Also the impact of the crop choice is less pronounced for Red List species compared with all species (Fig. 2c).

\section{Changes in species composition and total species number}

For comparison with the changes in species composition, Fig. 3 shows the percentage of area covered by first-generation biofuel crop plantations in the three biofuel policy options, also aggregated on $50 \mathrm{~km} \times$ $50 \mathrm{~km}$ level. The projected biofuel crop coverage varies notably among the countries as well as among the policy options. The proportion of arable land devoted to biofuel crops increases substantially in most countries when the biofuel target is increased. For the comparative analyses on woody biofuel crops, the same locations of biofuel plantations were assumed for the crop production (compare section 'Downscaling of species distribution maps').

The changes in species composition potentially occurring until 2030 and the additional impacts caused by a change in the biofuel target are shown in Figs 4 and 5, however focusing only on the strongest effects (potential species gain or loss $>50 \%$ ). The figures identify hotspots in Europe where $>50 \%$ of the local species might lose their entire habitat (potential species loss of $>50 \%$ ) and hotspots where the amount of species gaining new habitat at sites they were not present before amounts to $>50 \%$ of the local species (potential species gain $>50 \%$ ), if the current biofuel target was changed, and for the overall development between 2000 and 2030. Attention should be paid to the different classification scales when comparing the figures.

The following example shall help interpreting the figures on changes in species composition: A grid cell in the species gain maps which corresponds e.g. to class ' $3-5 \%$ ' indicates that on $3-5 \%$ of its area a potential species gain of $>50 \%$ occurs. Species gain of $>50 \%$ means that the number of species potentially gaining new habitat in that grid cell exceeds $50 \%$ of the species present in the cell under the current biofuel target (e2 policy option). In other words, if 15 species are present in a certain grid cell under the e1 option while they are not present in the same grid cell under the e 2 option, we observe a gain of 15 species for that cell when abolishing the biofuel target (comparison e1-e2, 'Abolishment of the target'). Relating these 15 species to the total number of species present in that grid cell under the e2 option, e.g. 25 species, would result in that case in a potential species gain of $>50 \%(15 / 25)$. Areas with potential species gain or loss of $<50 \%$ are not considered in the maps.

From the maps we can notice that the areas of potential species gain and loss do not necessarily overlap, indicating that the impact of biofuel crop 
(a) Abolishment of the current target (e1-e2)

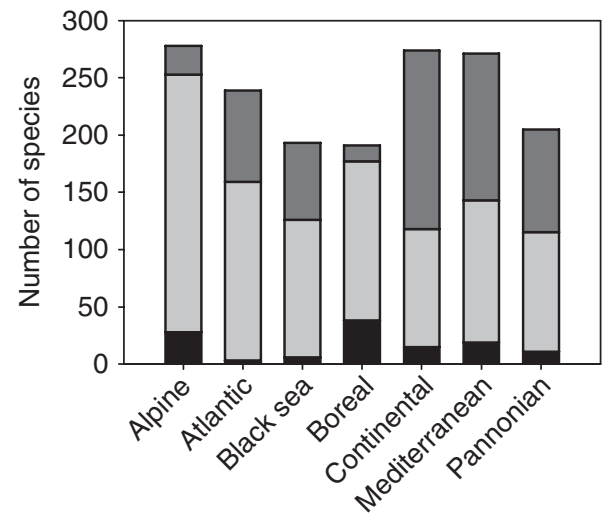

(c)

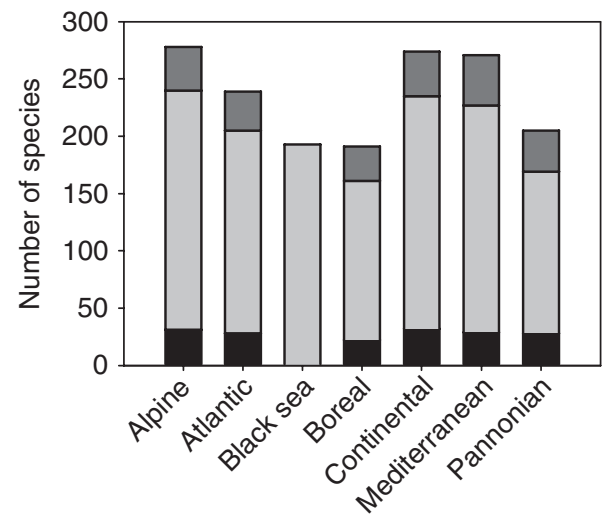

(b) Doubling of the current target (e3-e2)

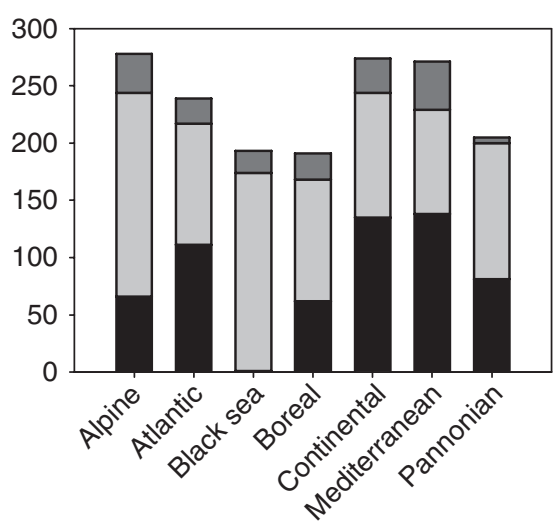

(d)

Overall changes 2000-2030 (e2-2000)

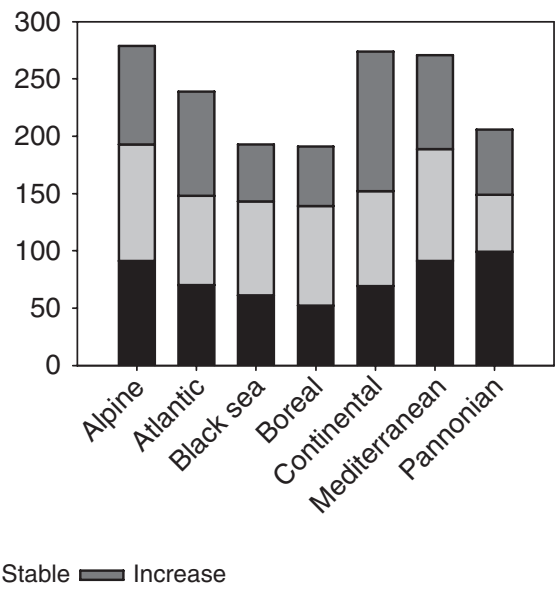

Fig 1 Total number of species possibly losing or gaining $>1 \%$ of their potential habitat if the biofuel target is abolished (a) or doubled (b), if the crop type is changed (c), and between 2000 and 2030 overall (d), per BGR. Figures are summarized for birds, mammals, reptiles and amphibians. BGR, biogeographical region.

production varies spatially. For example, when abolishing the biofuel target the area of potentially high species gain exceeds the area of potentially high species loss in the Mediterranean region, while the opposite is true for the Baltic countries. Overall, when abolishing the target, the area with a possible species gain of $>50 \%$ exceeds the area with potential species loss of $>50 \%$, while the effect is clearly the opposite when doubling the target (Fig. 5).

Putting our results into perspective of the overall changes between 2000 and 2030 (Fig. 4), we can see that the impacts of a different biofuel target (Fig. 5) are much smaller than the effects of the overall development until 2030. However, keeping in mind that the demonstrated potential impacts of changes in the EU biofuel policy would happen in addition to the overall changes until 2030, a different biofuel policy might alter the status of biodiversity considerably by 2030 . For example, espe- cially in the Baltic area, Poland and the United Kingdom, an abolishment or doubling of the biofuel target might strongly increase the already potentially high pressure on biodiversity between 2000 and 2030 (compare Figs 4 and 5).

If woody instead of arable crops are cultivated, the potential species loss and gain is high in the affected areas, because most species have a clear preference for either arable or woody crop habitats and do not occur in both habitats (Table 3, and see Fig. 3 for an overview of the affected areas in the three policy options). Species composition in the affected areas would thus change almost completely if woody instead of arable crops were cultivated.

A higher demand for biofuels will increase the pressure on seminatural land and forest throughout Europe. With very few exceptions, the area of seminatural land and forest as derived from the applied biofuel policy 


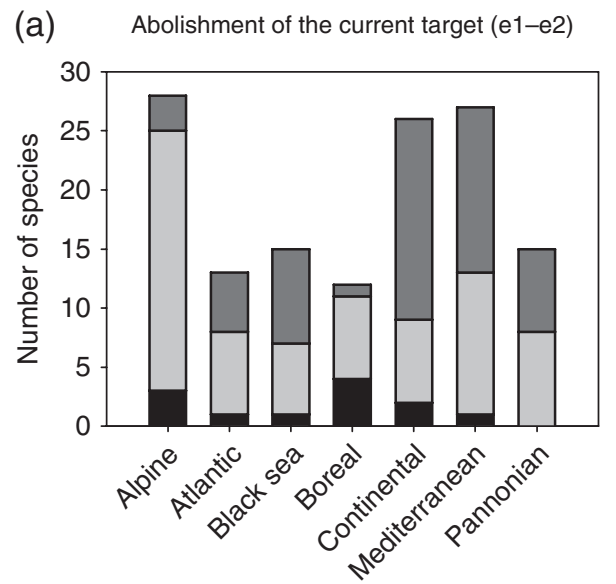

(b) Doubling of the current target (e3-e2)
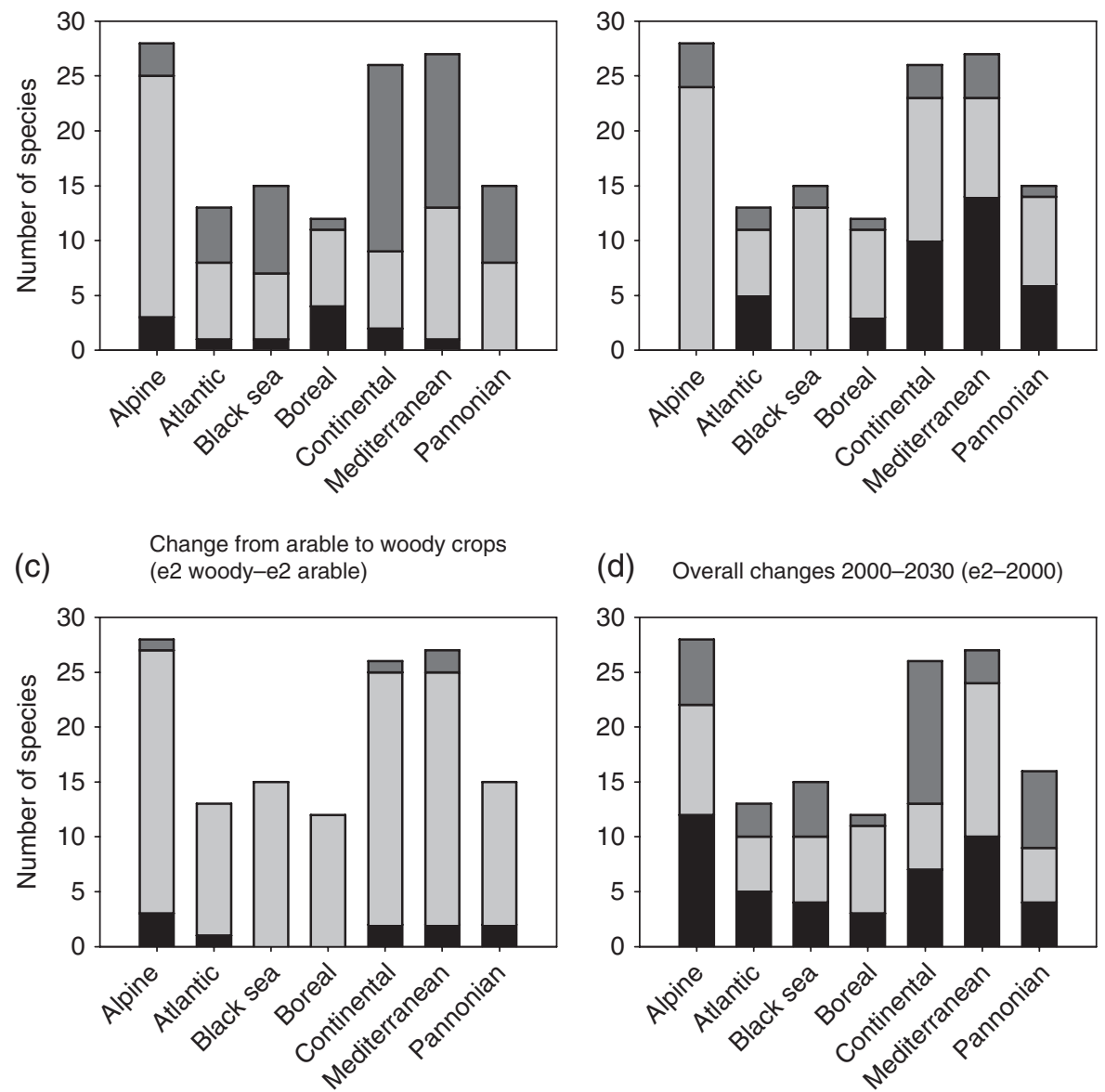

(d) Overall changes 2000-2030 (e2-2000)

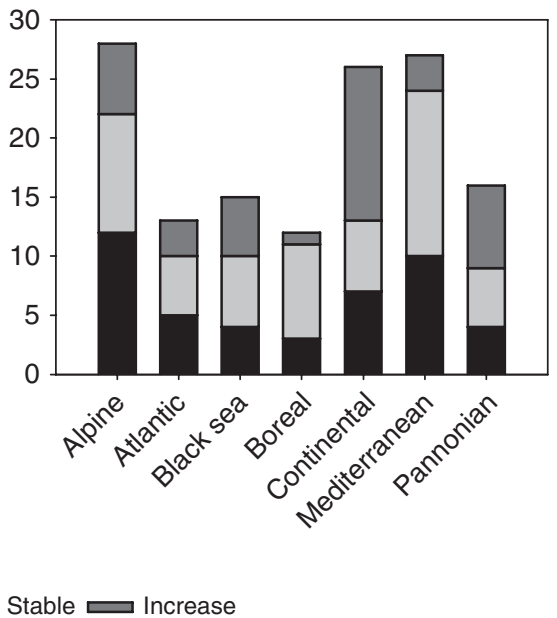

Fig 2 Number of IUCN Red list species possibly losing or gaining $>1 \%$ of their potential habitat if the biofuel target is abolished (a) or doubled (b), if the crop type is changed (c), and between 2000 and 2030 overall (d), per BGR. Given numbers of threatened species include the IUCN Red list categories 'near threatened', 'vulnerable', 'endangered', and 'critically endangered'. Figures are summarized for birds, mammals, reptiles and amphibians. BGR, biogeographical region.

options would decrease in the EU27 countries if the biofuel target was increased, also in countries where changes in biofuel plantation areas are small. The decrease of seminatural land and forest areas is smaller under a lower biofuel target, thus resulting in an increase of such areas when comparing the e1 with the e2 policy option ('Abolishment of the target'). As the change in pressure is effective throughout Europe, it impacts also places where biofuel production is stable between the policy options. This explains why an abolishment of the target results in a potentially positive impact on species abundance for example in Romania and Bulgaria, even though there are only small changes in local biofuel production between the three policy options (compare Figs 3 and 5). This phenomenon indicates that our results also reflect the indirect effects of the biofuels directive, i.e. impacts on species diversity do not only occur where biofuel production actually happens, but throughout Europe.

Despite the considerable impact on species composition when changing the biofuel policy, the total species number remains constant for most of the EU27 area (Table 4). That is, in most areas species loss and species gain are balancing each other out. The area in EU27 with a potential change in total species number resulting from a change in biofuel policy is rather small, showing an increase or decrease on mostly well below $2 \%$ of the area. For mammals, amphibians and birds, abolishing the biofuel target is beneficial, while doubling the target results in a net loss of species, indicating a negative impact of biofuel plantations for these species groups. For reptiles, the reference policy option e2 
Percentage of area covered with biofuel plantations
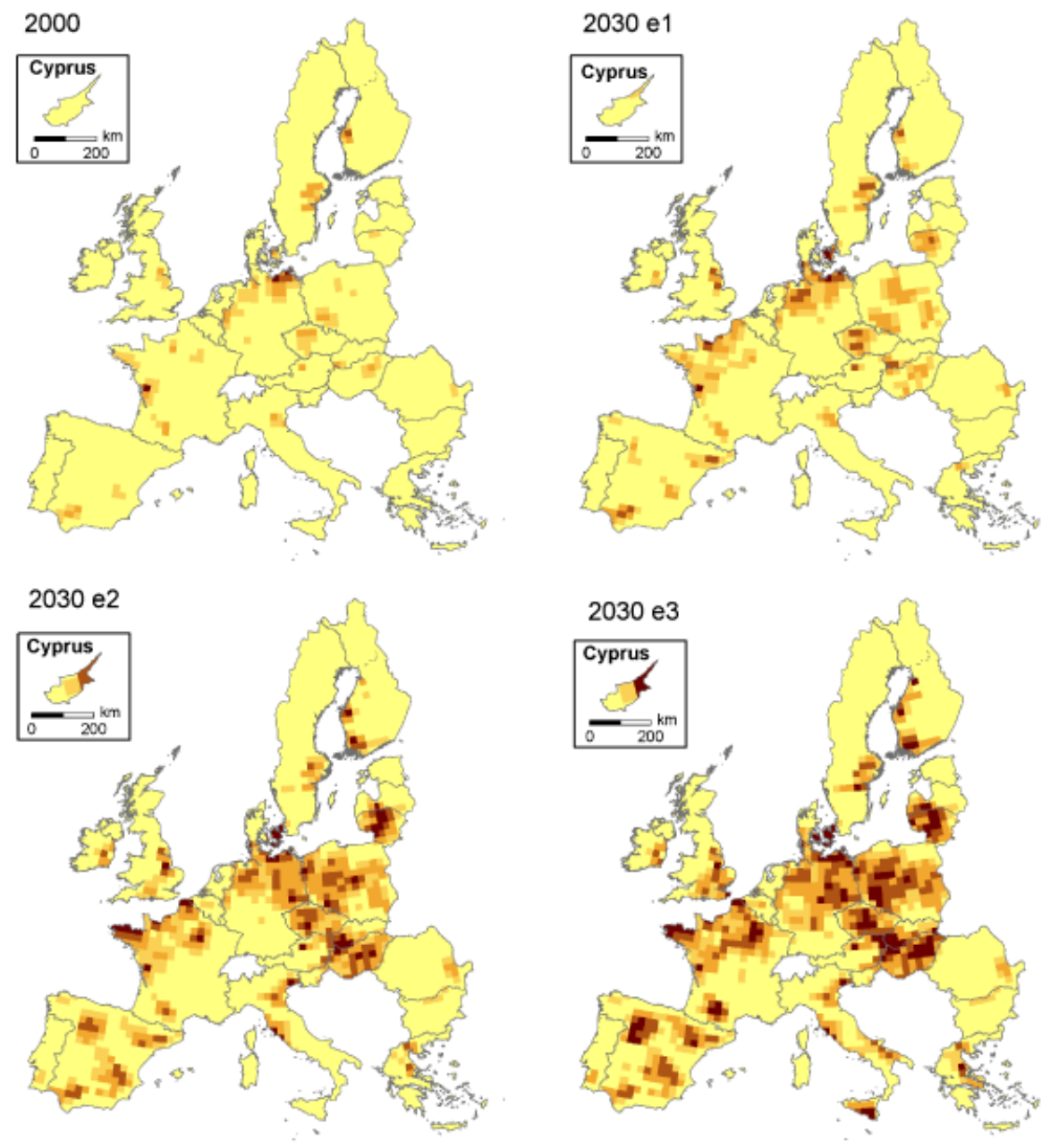

Percentage (\%)

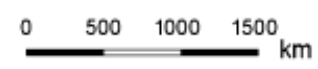

$2.5 \%$ or less $>2.5-5 \% \square>5-10 \% \square-15 \%$

$>15 \%$

Fig 3 Percentage of area covered with first-generation biofuel crop plantations per $50 \mathrm{~km} \times 50 \mathrm{~km}$ cell in 2000 and in 2030 , as projected by the EUruralis Global Economy scenario, for the biofuel policy options e1 ( $0 \%$ blending obligation), e2 (5.75\% blending obligation) and e3 (11.5\% blending obligation).

seems most favourable in terms of total species numbers, as both an abolishment and doubling of the target might have stronger negative than positive impacts. Doubling the biofuel target would potentially result in larger areas with negative changes in potential species numbers than abolishing the biofuel target. Mammals and birds seem more sensitive to a change in the biofuel crop choice than amphibians and reptiles. While mammals might only benefit from a change to woody crops in terms of species abundance, amphibians and birds seem more vulnerable to woody crop plantations.

Overall, changes in biofuel crop cultivation have only a small potential impact on total species numbers and available habitat in the EU27 area. Species abundance is much more affected by the overall changes occurring between 2000 and 2030. It can be concluded that of the four considered species groups mammals and birds will be affected the most.

\section{Discussion}

Using three specific biofuel policy options and habitat preferences of a large number of species, we demonstrated an innovative approach to assess the potential impacts of a change in the EU biofuel policy on biodiversity for a scenario of increased globalization of food, 
General development under the Global Economy scenario (2000-2030)
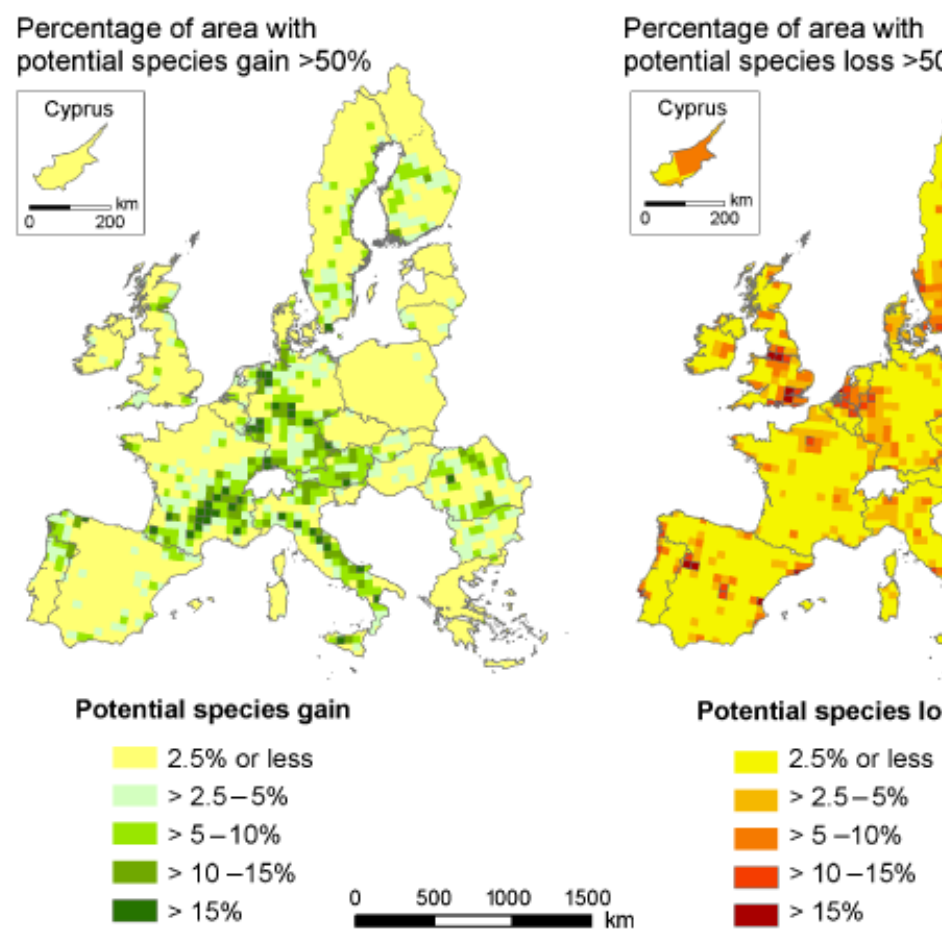

Fig 4 Percentage of area of $50 \mathrm{~km} \times 50 \mathrm{~km}$ cells where $>50 \%$ of the species might gain or lose their potential habitat due to the overall development between 2000 and 2030 as projected by the EUruralis Global Economy scenario. In terms of biofuel production, only the cultivation of arable (first-generation) biofuel crops is considered. Relative species shares are based on the total number of species in 2000. Figures are summarized for birds, mammals, reptiles and amphibians.

feed and fuel markets. With respect to the number of species and taxonomical groups covered, to date no comparable result has been published at the European level to our knowledge. We found that the impact of increased biofuel demands on biodiversity varies spatially, and that there are substantial differences between the species groups. Therefore, there is no straightforward answer to the question if biofuel policy harms biodiversity in Europe. However, our results indicate that more species might suffer from habitat losses rather than benefit from a doubling of the biofuel target. In addition to the effects of increased biofuel cultivation due to the higher biofuel demands as studied here, a higher biofuel target also reduces the potential for agricultural extensification and the enlargement of protected areas and set-aside land, with negative implication for biodiversity (Commission of the European Communities, 2006). The potential negative effect of increasing the biofuel target can be alleviated by careful crop selection - according to our analysis cultivating woody instead of arable crops would have an overall positive effect when looking at the combination of all species groups. This finding is in accordance with other studies, e.g. (Huston \& Marland, 2003; Gasc et al., 2004;
Biemans et al., 2008; CBD, 2008; Rowe et al., 2008), which state that for ligno-cellulosic crops, positive impacts on biodiversity are likely when compared with arable crops. However, when compared with replacement of set-aside and permanent unimproved grassland, effects are likely to be negative (Anderson \& Fergusson, 2006).

Nevertheless, it should be noted that the distinction between first-generation arable and second-generation woody crops made in this study is broad, as for each crop option a range of different choices exists (cereals, maize, sugar beet, poplar, willow, just to name a few), all of which show different characteristics. With the focus on short-rotation woody crops we neglect other second-generation ligno-cellulosic crops such as Miscanthus spp. or switchgrass (Panicum virgatum L.). The results may look very different when including the impacts of such energy grasses into the analyses. Furthermore, besides dedicated biofuel crops, there are several other sources for biofuels, including organic wastes, hay from species-rich grassland, and wood residues from forestry. These sources were neglected in this study, as they have no or only limited direct impacts on land use. 
What might happen if we abolish or double the biofuel target?

Percentage of area with potential species gain of $>50 \%$

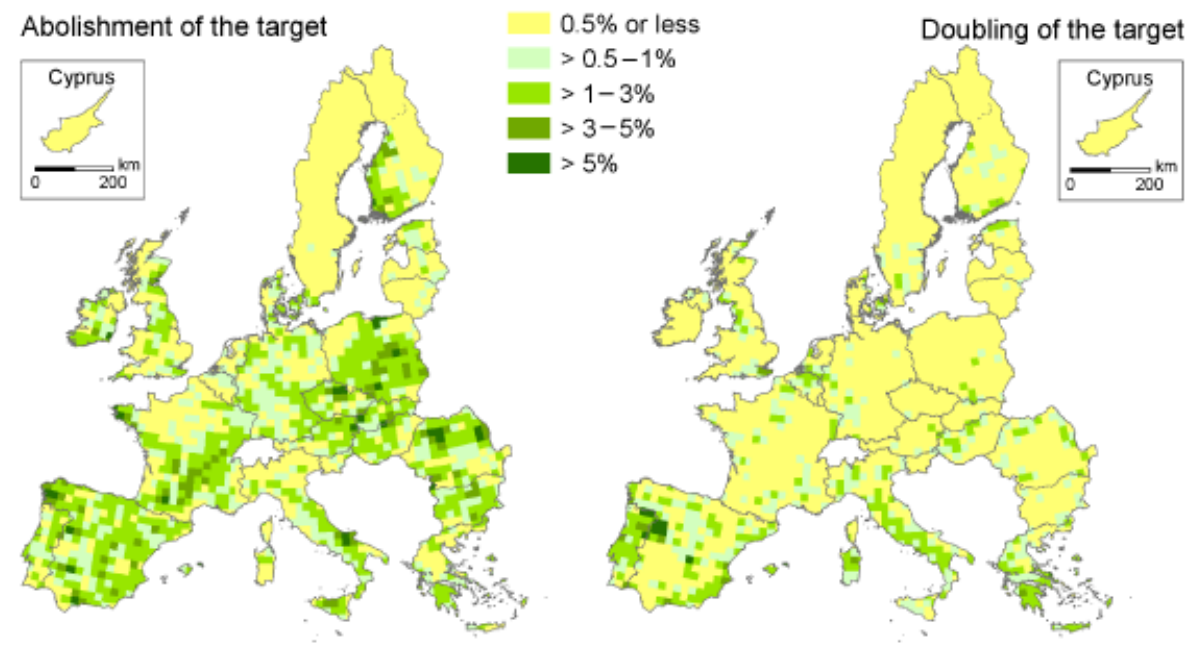

Percentage of area with potential species loss of $>50 \%$

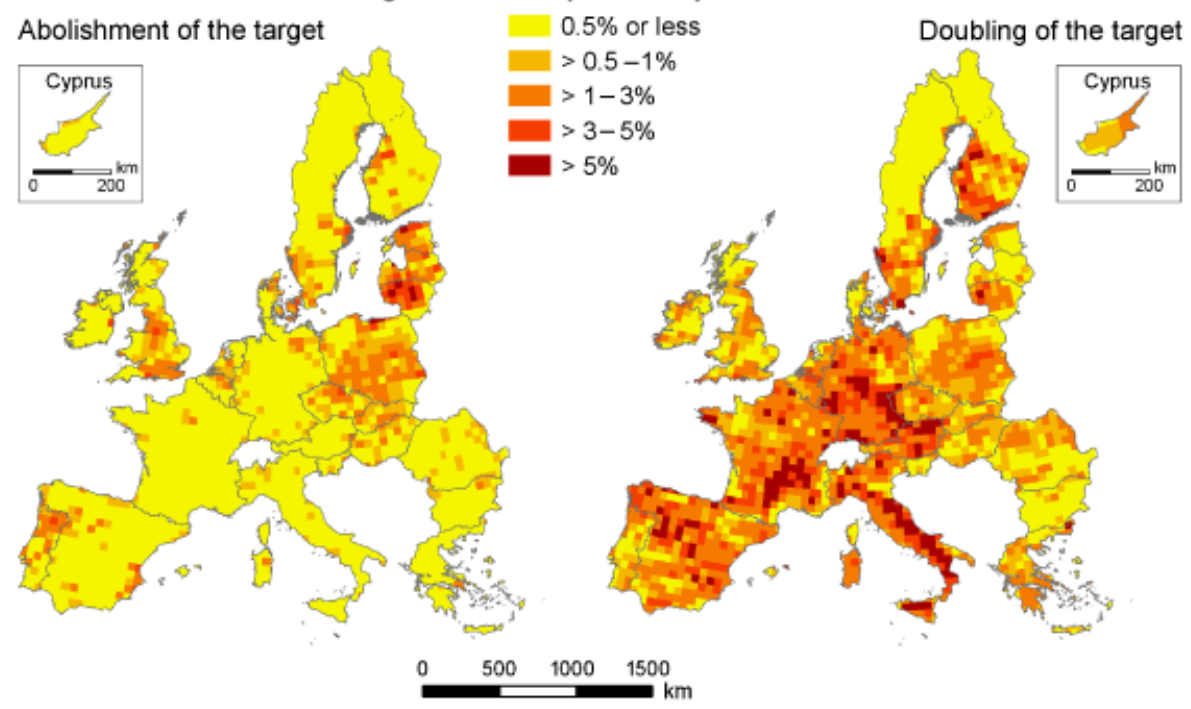

Fig 5 Percentage of area of $50 \mathrm{~km} \times 50 \mathrm{~km}$ cells where $>50 \%$ of the species would gain or lose their potential habitat when abolishing or doubling the current biofuel target. Only the cultivation of arable (first-generation) biofuel crops is considered. Relative species shares are based on the total number of species in policy option e2 ( = reference policy option, reflecting the current biofuel target of $5.75 \%$ ). Figures are summarized for birds, mammals, reptiles and amphibians.

In the absence of a specific woody biofuel crop scenario, we assumed that woody crops would be cultivated at the sites dedicated to arable biofuel crops in the biofuel scenarios. However, given their demands for suitable climate and water availability, the cultivation of woody biofuel crops will most likely be concentrated in the Boreal, Atlantic and Continental zone in the near future, while countries in the Mediterranean and Alpine zone are likely to focus on other biofuel crops (Tuck et al., 2006). But even though arable and woody biofuel crops would not necessarily be cultivated at the same site, the comparison between the two
Table 3 Number of species with medium or high suitability level for the arable and woody biofuel crop option

\begin{tabular}{llclc}
\hline & Amphibians & Mammals & Reptiles & Birds \\
\hline Arable & 2 & 7 & 1 & 27 \\
Woody & 2 & 18 & 6 & 22 \\
Both & 1 & 2 & 0 & 2 \\
\hline
\end{tabular}

crop types gives valuable insight on their respective possible impacts on biodiversity. As Hellmann \& Verburg (2008) have shown, the allocation of arable and woody biofuel crops might follow similar patterns 
Table 4 Percentage of the EU27 area showing a possible decrease, no change, or increase in potential species number (number of species with medium and high suitable habitat) if the current biofuel target is abolished or doubled, if the crop type is changed (woody-arable), and between 2000 and 2030 overall (e2-2000)

\begin{tabular}{|c|c|c|c|c|}
\hline & $\begin{array}{l}\text { Overall change } \\
\text { between } \\
2000 \text { and } 2030 \\
\text { Comparison } \\
\text { e2-2000 (\%) }\end{array}$ & $\begin{array}{l}\text { What might change } \\
\text { in addition if we abolish } \\
\text { the current biofuel target? } \\
\text { Comparison e1-e2 (\%) }\end{array}$ & $\begin{array}{l}\text { What might change } \\
\text { in addition if we double } \\
\text { the current biofuel target? } \\
\text { Comparison e3-e2 (\%) }\end{array}$ & $\begin{array}{l}\text { What might change in } \\
\text { addition if we cultivate } \\
\text { woody instead of arable } \\
\text { crops? Comparison } \\
\text { woody-arable in e2 }(\%)\end{array}$ \\
\hline \multicolumn{5}{|l|}{ Amphibians } \\
\hline Decrease & 2.9 & 0.3 & 1.4 & 0.7 \\
\hline No change & 92.9 & 98.8 & 98.1 & 99.0 \\
\hline Increase & 4.2 & 0.9 & 0.5 & 0.3 \\
\hline \multicolumn{5}{|l|}{ Reptiles } \\
\hline Decrease & 2.9 & 0.8 & 1.2 & 0.3 \\
\hline No change & 94.5 & 99.0 & 98.5 & 99.5 \\
\hline Increase & 2.6 & 0.3 & 0.4 & 0.2 \\
\hline \multicolumn{5}{|l|}{ Mammals } \\
\hline Decrease & 5.2 & 0.4 & 1.8 & 0.0 \\
\hline No change & 90.8 & 98.6 & 97.8 & 97.4 \\
\hline Increase & 4.0 & 1.1 & 0.4 & 2.6 \\
\hline \multicolumn{5}{|l|}{ Birds } \\
\hline Decrease & 4.7 & 0.6 & 1.6 & 1.5 \\
\hline No change & 90.2 & 98.4 & 97.5 & 97.7 \\
\hline Increase & 5.2 & 1.0 & 0.9 & 0.7 \\
\hline \multicolumn{5}{|c|}{ Total for all species groups } \\
\hline Decrease & 4.6 & 0.6 & 1.8 & 0.1 \\
\hline No change & 90.1 & 98.3 & 97.5 & 97.4 \\
\hline Increase & 5.3 & 1.1 & 0.8 & 2.5 \\
\hline
\end{tabular}

as that of conventional biofuels because its cultivation and management also needs locations that are suitable for efficient cultivation and transport to processing industries. The technical development needed to make processing of these crops possible will determine the most efficient scale of processing and the most preferred locations of this industry. Given the high costs of transportation of these high-volume crops, these factors will be of prime importance for the selection of locations where the cultivation of such crops will become profitable. Preliminary simulations by Hellmann and Verburg (2008) indicate that, to some extent, hotspots of lignocellulosic crops clearly overlap with hotspots of arable biodiesel/bioethanol crops. Therefore the assumptions used in this paper may give a good indication of the possible consequences of woody biofuel cultivation for biodiversity.

The impact of biofuel crop cultivation on biodiversity depends on a combination of various effects (Anderson et al., 2004; Anderson \& Fergusson, 2006; Firbank, 2008): local scale effects such as the choice of crop, management intensity and vegetation structure, the biodiversity value of the crop relative to the land-use types which it replaces, as well as landscape scale effects, such as the geographical location, the scale and the spatial distribution of the crops. It is important to stress that our results reflect the impacts of biofuel policies solely on land-use changes, while the implications of such policies go beyond that. With our analyses we neglected other possible effects of biofuel crop production on biodiversity, such as the use of pesticides, ground water depletion, introduction of alien and invasive species, or greenhouse gas emissions resulting from the production cycle (CBD, 2008). There are also likely effects on production intensity as a result of the biofuels directive on all agricultural lands. We may underestimate the effects on biodiversity since we do not consider the intensification in agricultural practices linked to an increase in the biofuel target. For example, when high-nature value farmlands in Eastern Europe are replaced by intensive biofuel plantations, the land use class and thus the assumed habitat suitability do not change in our analyses, while the effect will be negative for many species. The IRENA study (EEA, 2005a) concluded that extensive farming systems are important for maintaining the biological and landscape diversity of farmland, including Natura2000 sites and High Nature Value farmland (EEA, 2007). 
Since a part of the biofuels consumed in the EU27 is imported, biofuel policy has an impact on biodiversity in other world regions, too. For example, the destruction of tropical forests, which are rich in biodiversity, are heavily linked to the booming biofuel industry (Koh, 2007; Tan et al., 2008). Though important, such effects outside the EU27 area were out of the scope of our study.

Uncertainties exist with regard to the input data and the approach adopted in this study. It should be noted that we included only $23 \%$ of the amphibian, $13 \%$ of the reptile, $39 \%$ of the bird and $20 \%$ of the mammal species occurring in Europe in our analysis, while other relevant species groups such as butterflies and beetles were excluded. The distribution data for the selected species at a European level have serious drawbacks in terms of timeliness and accuracy (see Delbaere \& Nieto Serradilla, 2004) but to date form the best available data for the type of analyses carried out here. The allocation and area of biofuel crop plantations as used in our study are based on the variation of the EU biofuel policy within one scenario of development of economy, demography and policies. Within the EUruralis project (WUR, MNP, 2008) different alternative scenarios were analysed resulting in different land use change effects. Only for the Global Economy scenario which was applied in this paper all three policy options concerning the biofuels directive were available. Thus, it should be noted that the results of this paper are only valid against the background of the assumptions of the Global Economy scenario. In other scenarios the impact of biofuel policy may be different due to different world trade conditions and different land market conditions. Also for each scenario different assumptions were made concerning the scale of production of biofuels and their processing, transport costs and restricted zones consistent with the overall storyline of the scenario (Hellmann \& Verburg, 2008). The scenario used in this paper is based on the assumption that processing industry will reach levels similar to the largest of the current bioenergy crop processing industries, and few restrictions concerning the allocation of biofuels are included due to the assumed low levels of government intervention under this scenario. Furthermore, in the Global Economy scenario high levels of land abandonment are predicted as a continuation of the current trend in mountainous regions. In other EUruralis scenarios, and also with respect to the given current agricultural development globally, lower rates of land abandonment are foreseen and thus, the context of biofuel impacts on European land use may be different. Less land abandonment is e.g. likely to increase import rates from outside Europe. Thus, the results of this paper should be interpreted given the overall scenario while a full ex-ante assess- ment of the biofuels directive should include multiple scenarios as a context.

However, increasing ambitions on biofuels in other world regions are disregarded in the current implementation of the biofuel policy options. In the Global Economy scenario about half of the biofuels are projected to be imported (Banse et al., 2008), but rising biofuel ambitions elsewhere will make it more difficult to import and the pressure on land in Europe will be higher. Furthermore, imports of food and feed will also be affected if other world regions increase their biofuel ambitions. So it is likely that the land use scenarios underestimate some of the effects.

Furthermore, the spatial distribution of the potential habitat for the species as derived from the land use projections and the habitat suitability levels from the BioScore database can only serve as a coarse estimation of the actual habitat. We did not consider parameters such as climate, management intensity, disturbances, interactions among species, small-scale habitat structure and species dispersal abilities, which also influence species occurrence. Moreover, species responses to a changing environment are very unpredictable and therefore we can only give an indication of proportions of species that are sensitive to a given land use change rather than actually predicting impacts.

In our approach we assume that a species only occurs in areas with available habitat of medium or high suitability, and that the loss of such habitat results in the loss of the species linked to it. Vice versa, we assume that a gain of such habitat leads to the presence of additional species linked to that habitat. However, this may not always be the case because species responses are complex as stated above. Therefore we possibly overestimate potential changes in species composition.

All analyses are based on habitat suitability specified for the CORINE land cover classes by BGR. This is only a generalization of the actual habitat preferences of the species and does not reflect specific habitat requirements. For example, the long-fingered bat (Myotis capaccinii) is dependent on Black alder (Alnus glutinosa), White willow (Salix alba) or European ash (Fraxinus excelsior) woodland near flowing water, but in our analysis it was assigned high suitability for any broadleaved forest, as in CORINE all broadleaved forests are included in one class. Moreover, habitat suitability levels were aggregated to conform to the classification scheme of the EUruralis projections. For this reason the results of this study might overestimate habitat suitability for those land use classes in the scenarios which overlapped with several CORINE classes since the maximum of the suitability levels for the overlapping CORINE classes was used in such case (compare section 'Downscaling of species distribution maps'). Thus, our 
results might underestimate the potential impact of a change in biofuel ambitions on biodiversity. However, for the applied scenario comparisons the influence of the overestimation of habitat suitability is balanced out as the same aggregation method was applied for all downscaled distribution maps for the three biofuel policy options (e1, e2 and e3). Besides the restriction to the CORINE classes, we were limited to only four habitat suitability levels (no, low, medium, high suitability) which were further combined to potential presence and absence. Such 'black and white' perspective can only give a rough indication of the real species distribution.

The restriction to the CORINE land cover classes puts limits on the characterization of habitat suitability for woody and arable biofuel crops. There is no explicit CORINE class for short-rotation woody plantations. Thus, following the consultation of species experts, it was assumed that the CORINE class 'fruit trees and berry plantations' is closest in its characteristics. The main argument for this choice is that both short-rotation woody plantations and fruit tree plantations are plantations without understory in which human disturbances occur at regular intervals. However, by doing so, we neglect impacts of specific management practices related to the cultivation of short-rotation coppice such as harvesting techniques or usage of pesticides. Furthermore, fruit tree plantations offer food possibilities for micro-mammals and birds, a characteristic which is not present in such extent for woody biofuel crop plantations. Therefore, associating woody crop plantations with the habitat suitability level of fruit trees and berry plantations probably gives an overoptimistic view on habitat suitability. When applying the habitat suitability levels of CORINE class 'arable land' for the arable biofuel crop option, we assume that both management systems - crop cultivation for food production and crop cultivation for fuel production - are the same from the perspective of habitat suitability for the species. In this case we neglect possible differences between both systems such as the probably lower use of pesticides and herbicides for biomass crops as well as different harvesting periods and techniques (EEA, 2007), which can have an impact on habitat suitability.

The IUCN Red list conservation status for the species considered in this study was aggregated at the level of BGR. Local differences in the Red list status could not be considered. Thus the number of potentially affected threatened species will be different in areas where local populations are of other conservation status than the one assumed at BGR level.

We would also like to point out, that the aggregated results in all given figures reflect mainly the potential impacts of biofuel production on the species groups with highest species numbers in the BioScore database (birds and mammals).

Even though there are uncertainties related to the input data and the approach followed, our results give an indication for policy and decision makers of what might happen under a changed biofuel policy in the EU. The method has the potential to be applied in future analyses as it is flexible in scale and can be extended to other species groups provided that required input data are available. Possible improvements relate to the availability of detailed land use scenarios and the integration of further parameters regarding species occurrence.

\section{Acknowledgements}

The research was carried out within the BioScore project (Biodiversity impact assessment using species sensitivity scores, http://www.bioscore.edu). BioScore is cofinanced by the European Commission as a Strategic Research Project (contract number 022661) under the Sixth Framework Programme for Research and Technological Development. Other finance is provided by the partners in the BioScore team. The BioScore team, led by ECNC, is solely responsible for the content of this paper. It does not represent the opinion of the European Community, nor is the EC responsible for any use that might be made of information appearing herein. We would like to thank the whole BioScore team for compiling the species-specific habitat suitability data and setting up the BioScore database.

\section{References}

Åhman M, Nilsson LJ (2008) Path dependency and the future of advanced vehicles and biofuels. Utilities Policy, 16, 80-89.

Anderson GQA, Fergusson MJ (2006) Energy from biomass in the UK: sources, processes and biodiversity implications. Ibis, 148, 180-183.

Anderson GQA, Haskins L, Nelson S (2004) The effects of bioenergy crops on farmland birds in the UK: a review of current knowledge and future predictions. In: Biomass and Agriculture; Sustainability, Markets and Policies (eds Parris K, Poincet T), pp. 199-218. OECD, Paris.

Banse M, van Meijl H, Tabeau A, Woltjer G (2008) Will EU biofuel policies affect global agricultural markets? European Review of Agricultural Economics, 35, 117-141.

Biemans M, Waarts Y, Nieto A, Goba V, Jones-Walters L, Zöckler C (2008) Impacts of biofuel production on biodiversity in Europe. ECNC - European Centre for Nature Conservation, Tilburg, the Netherlands, $31 \mathrm{pp}$.

CBD (2008) The potential impacts of biofuels on biodiversity. Matters arising from SBSTA recommendation XII/7. UNEP/CBD/ COP/9/26. Convention on Biological Diversity, 16 pp.

Commission of the European Communities (2005) Communication from the Commission: Biomass action plan. Brussels, 7.12.2005. COM(2005) 628 final.

Commission of the European Communities (2006) Commission staff working document: Annex to the Communication from the Commission "An EU Strategy for Biofuels", Impact Assessment. $\operatorname{COM}(2006) 34$ final, Brussels. 
Commission of the European Communities (2008) Proposal for a Directive of the European Parliament and of the Council on the promotion of the use of energy from renewable sources, $\operatorname{COM}(2008) 19$ final.

Delbaere B (2006) European policy review - Assessing policy impacts on biodiversity. Journal of Nature Conservation, 14, 129130.

Delbaere B, Nieto Serradilla A (eds) (2004) Environmental Risks from Agriculture in Europe: Locating Environmental Risk Zones in Europe Using Agri-Environmental Indicators. ECNC - European Centre for Nature Conservation, Tilburg.

EEA (2000) CORINE land cover technical guide - Addendum 2000. Technical report no. 40. European Environment Agency, Copenhagen, $105 \mathrm{pp}$.

EEA (2005a) Agriculture and environment in EU-15 - the IRENA indicator report. EEA report no 6/2005. European Environment Agency, Copenhagen, 128 pp.

EEA (2005b) Biogeographical regions, Europe 2005. European dataset, scale $>=1: 10.000 .000$, vector format. European Environment Agency, Copenhagen. URL at: http://dataservice. eea.europa.eu/dataservice/metadetails.asp?id=839 (accessed on 20.03.2008).

EEA (2006) Energy and environment in the European Union: Tracking progress towards integration. EEA report no. 8/2006. European Environment Agency, Copenhagen, $52 \mathrm{pp}$.

EEA (2007) Estimating the environmentally compatible bioenergy potential from agriculture. Technical report. European Environment Agency, Copenhagen, 134 pp.

Eickhout B, van den Born GJ, Notenboom J, van Oorschot M, Ros JPM, van Vuuren DP, Westhoek HJ (eds) (2008) Local and Global Consequences of the EU Renewable Directive for Biofuels. Testing the Sustainability Criteria. Netherlands Environmental Assessment Agency, Bilthoven.

Eickhout B, van Meijl H, Tabeau A, van Rheenen T (2007) Economic and ecological consequences of four European land use scenarios. Land Use Policy, 24, 562-575.

Faaij APC (2006) Bio-energy in Europe: changing technology choices. Energy Policy, 34, 322-342.

Fargione J, Hill J, Tilman D, Polasky S, Hawthorne P (2008) Land clearing and the biofuel carbon debt. Science, 319, 12351238.

Farrell EE, Plevin RJ, Turner BT, Jones AD, O'Hare M, Kammen DM (2006) Ethanol can contribute to energy and environmental goals. Science, 311, 506-508.

Firbank L (2008) Assessing the ecological impacts of bioenergy projects. Bioenergy Research, 1, 12-19.

Gasc J-P, Cabela A, Crnobrnja-Isailovic J et al. (eds) (2004) Atlas of Amphibians and Reptiles in Europe. Societas Europea Herpetologica \& Museum National d'Histoire Naturelle, Paris.

Hagemeijer WJM, Blair MJ (eds) (1997) The EBCC Atlas of European Breeding Birds - their Distribution and Abundance. $\mathrm{T} \&$ A Poyser, London.

Harvey J (2007) A versatile solution? Growing Miscanthus for bioenergy. Renewable Energy World, 10, 86-93.

Hellmann F, Verburg PH (2008) Spatially explicit modelling of biofuel crops in Europe. Biomass and Bioenergy, doi: 10.1016/ j.biombioe.2008.09.003.
Huston MA, Marland G (2003) Carbon management and biodiversity. Journal of Environmental Management, 67, 77-86.

IUCN (2008) 2008 IUCN Red List of threatened species, http:// www.iucnredlist.org

Kahn Ribeiro S, Kobayashi S, Beuthe M et al. (2007) Transport and its infrastructure. In: Climate Change 2007: Mitigation. Contribution of Working Group III to the Fourth Assessment Report of the Intergovernmental Panel on Climate Change (eds Metz B, Davidson OR, Bosch PR, Dave R, Meyer LA), Cambridge University Press, Cambridge, pp. 323-386.

Karp A, Shield I (2008) Bioenergy from plants and the sustainable yield challenge. New Phytologist, 179, 15-32.

Koh LP (2007) Potential habitat and biodiversity losses from intensified biodiesel feedstock production. Conservation Biology, 21, 1373-1375.

Koh LP, Ghazoul J (2008) Biofuels, biodiversity, and people: understanding the conflicts and finding opportunities. Biological Conservation, 141, 2450-2460.

Linnell J, Salvatori V, Boitani L (2007) Guidelines for population level management plans for large carnivores in Europe. A Large Carnivore Initiative for Europe report prepared for the European Commission. Final draft May 2007.

Louette G, Maes D, Alkemade JRM et al. BioScore - cost-effective assessment of policy impact on biodiversity using species sensitivity scores. Global Environmental Change.

Mace GM (2004) The role of taxonomy in species conservation. Philosophical Transactions of the Royal Society London B, 359, 711719.

Maiorano L, Falcucci A, Garton EO, Boitani L (2007) Contribution of the Natura 2000 Network to Biodiversity Conservation in Italy. Conservation Biology, 21, 1433-1444.

Marshall L (2008) The biofuel gamble. Why the swing to green energy holds promise and danger. African Wildlife, 62, $18-21$.

Mathiesen BV, Lund H, Nørgaard P (2008) Integrated transport and renewable energy systems. Utilities Policy, 16, 107116.

Mitchell-Jones AJ, Amori G, Bogdanowicz W et al. (1999) The Atlas of European Mammals. The Academic Press, London.

Nakicenovic N, Swart R (eds) (2000) Special Report on Emission Scenarios. Cambridge University Press, Cambridge, UK.

Quadrelli R, Peterson S (2007) The energy-climate challenge: recent trends in $\mathrm{CO}_{2}$ emissions from fuel combustion. Energy Policy, 35, 5938-5952.

Raghu S, Anderson RC, Daehler AS, Wiedenmann RN, Simberloff D, Mack RN (2006) Adding biofuels to the invasive species fire. Science, 313, 1742.

Rienks WA (ed) (2008) The Future of Rural Europe. An Anthology Based on the Results of the Eururalis 2.0 Scenario Study. Wageningen University Research and Netherlands Environmental Assessment Agency, Wageningen, the Netherlands.

Rowe RL, Street NR, Taylor G (2009) Identifying potential environmental impacts of large-scale deployment of dedicated bioenergy crops in the UK. Renewable and Sustainable Energy Reviews, 13, 271-290.

Russi D (2008) An integrated assessment of a large-scale biodiesel production in Italy: killing several birds with one stone? Energy Policy, 36, 1169-1180. 
Schmer MR, Vogel KP, Mitchell RB, Perrin RK (2008) Net energy of cellulosic ethanol from switchgrass. Proceedings of the National Academy of Sciences USA, 105, 464-469.

Simeonova K (2005) Integrated climate-change strategies of industrialized countries. Energy, 30, 2537-2557.

Sims REH, Hastings A, Schlamadinger B, Taylor G, Smith P (2006) Energy crops: current status and future prospects. Global Change Biology, 12, 2054-2076.

Solomon S, Qin D, Manning M et al. (2007) Technical Summary. In: Climate Change 2007: The Physical Science Basis. Contribution of Working Group I to the Fourth Assessment Report of the Intergovernmental Panel on Climate Change (eds Solomon S, Qin D, Manning M, Chen Z, Marquis M, Averyt KB, Tignor M, Miller HL), Cambridge University Press, Cambridge, pp. 19-92.

Tan KT, Lee KT, Mohamed AR (2008) Role of energy policy in renewable energy accomplishment: the case of second-generation bioethanol. Energy Policy, 36, 3360-3365.

Temple HJ, Terry AC (2007) The Status and Distribution of European Mammals. Office for Official Publications of the European Communities, Luxembourg .

Tuck G, Glendining MJ, Smith P, House JI, Wattenbach M (2006) The potential distribution of bioenergy crops in Europe under present and future climate. Biomass and Bioenergy, 30, 183-197.

USGS (2006) GTOPO30 Hydro $1 k$ dataset - hydrologically correct digital elevation model for Europe, $1 \mathrm{~km}$ resolution. URL at: http://edc.usgs.gov/products/elevation/gtopo30/hydro/ eu_dem.html (accessed on 20.03.2008).

van Meijl H, van Rheenen T, Tabeau A, Eickhout B (2006) The impact of different policy environments on agricultural land use in Europe. Agriculture, Ecosystems \& Environment, 114, 21-38.
Verburg PH, Bakker M, Overmars KP, Staritsky I (2008) Landscape level simulation of land use change. In: Sustainability Impact Assessment of Land Use Changes (eds Helming K, PérezSoba M, Tabbush P), Springer, Berlin, pp. 211-227.

Verburg PH, Schulp CJE, Witte N, Veldkamp A (2006) Downscaling of land use change scenarios to assess the dynamics of European landscapes. Agriculture, Ecosystems and Environment, 114, 39-56.

Westhoek HJ, van den Berg M, Bakkes JA (2006) Scenario development to explore the future of Europe's rural areas. Agriculture, Ecosystems and Environment, 114, 7-20.

Wright L (2006) Worldwide commercial development of bioenergy with a focus on energy crop-based projects. Biomass and Bioenergy, 30, 706-714.

WUR, MNP (2008) Eururalis 2.0 DVD. Available via internet: http://www.eururalis.eu/app/register.html

\section{Supporting Information}

Additional Supporting Information may be found in the online version of this article:

Table S1. List of species considered in our study.

Please note: Wiley-Blackwell are not responsible for the content or functionality of any supporting materials supplied by the authors. Any queries (other than missing material) should be directed to the corresponding author for the article. 